\title{
From a De-politicization Duty of Care to a Deeply Politicized Phenomenon: Navigating the Tension between Classical and New Humanitarianism
}

\author{
Jacinta Chiamaka Nwaka \\ https://dx.doi.org/10.4314/ujah.v22i2.2
}

\begin{abstract}
The doctrine of Responsibility to Protect popularly known as R2P was adopted by the international community as a response to complex emergencies of the post-Cold War era. Nearly two decades of its proposal and adoption, R2P is still a controversial doctrine that is yet to go down well with most humanitarian organizations especially relief agencies. Consequently, humanitarian organizations engaging in humanitarian assistance often dissociate their activities in theory and practice from R2P. Despite the challenges which the doctrine poses to humanitarian actors, this study, using historical and analytical method, demonstrates that there are common grounds from which a synergy could be built for effective intervention and assistance. Such grounds, it posits exist because the rejection of R2P by humanitarian actors is not informed by inadequacies in the content of the new framework, as both old and new humanitarianism appear to be pursuing similar goal - protection of the helpless victims of war. What constitutes a difference seems to be too much space in $\mathrm{R} 2 \mathrm{P}$ which could be exploited by the powerful states for personal gain and which also stifles the implied but most important aspect of the doctrine - responsibility in protection.
\end{abstract}




\section{Introduction}

The end of the Cold War ushered in an era of intra-state wars characterized by some states' inability or unwillingness to protect its citizens (Kaldor 2006). Complex emergencies occasioned by this development set in motion the search for an instrument of prevention and intervention against atrocities emanating from the post-Cold War new wars. Arguing that sovereignty connotes responsibility, the UN General Assembly adopted, under the concept of new humanitarianism, the doctrine of Responsibility to Protect (R2P) bypassing the absoluteness embedded in Westphalian sovereignty (UN, 2005). Since its adoption, R2P has generated a lot of tensions. Its first test in Libya in 2011opened up a Pandora box of criticisms from academics, policy makers, civil society organizations and practitioners, who decried what appeared to be the instrumentation of such framework by the most powerful states of the world (Chilaka et al, 2012). One of the groups that seem not to be comfortable with $\mathrm{R} 2 \mathrm{P}$ is humanitarian organizations, especially relief organizations. Despite the optimism of the framers and advocates of the doctrine that humanitarian operations carried out by humanitarian organizations will be integrated into the new framework, the manner with which some relief organizations struggle to distance their humanitarian engagements from R2P in conflict areas is not only worrisome but enough to convince one who is not familiar with the underlying principles of R2P that the framework is not within the realm of humanitarianism at all. The paper is, therefore, geared towards a more understanding of the basis of the tension between humanitarian actions as pursued by humanitarian organizations and 
Nwaka: From a De-politicization Duty of Care...

$\mathrm{R} 2 \mathrm{P}$, as well as some common grounds from which such gaps could be circumscribed for optimal performance.

Literature on R2P is not scanty. A lot of works have captured the limitations of the framework from various dimensions (Mandani, 2010; Chandler, 2006, 2010, 2015; Paris, 2014; Puri, 2016; Hall, 2016). R2P is equally lauded in literature as a policy whose time has come (Thakur, 2017; Sampford and Thakur, 2015; Dunne and Staunton, 2016; Weiss, 2011). Some other works have dwelt on possible ways of strengthening the framework to make it more effective (Evans 2017: Acharya, 2013: 2015). The tension between R2P and humanitarian assistance is equally captured by Okeke (2010), De-Terrence (2004), Macrae (2000) and Mills (2005). However, while the basis of the tension may have been established, possible areas for synergistic actions seem not to have been well represented in literature. It is some of these areas of common grounds that this study seeks to highlight for possible integration. The study will use both historical and analytical method within qualitative research methodology to trace the development from classical humanitarianism to R2P, analyse the basis of hindrances to integration and identify possible areas of synergy.

\section{From Traditional to New Humanitarianism}

Humanitarian intervention traditionally evolved as a non-statist, depoliticized and neutral duty of care. Pioneered by Jean Henri Dunant, who founded the International Committee of the Red Cross 
(ICRC) following his experience at the battle of Soferino, other humanitarians - Florence Nightingale, Clara Burton and Frances Lieber, who manifested similar inclinations to compassion, furthered the course of humanitarianism. The advocacies of these earlier humanitarians especially the ICRC was instrumental to the 1864 and 1949 Geneva Conventions which laid some guidelines for humane treatment of victims of war and development of International Humanitarian Law (IHL) respectively. In addition to its effort to influence, positively, war conducts, traditional humanitarianism was equally anchored on delivery of relief supplies and services to victims of conflict and natural disaster. In pursuant of such programs, most relief organizations, especially the ICRC, try to adhere strictly to what the latter identified as core principles of humanitarian action namely: impartiality, neutrality, independence and humanity. These principles present classical humanitarian bodies as politically-neutral organizations that are specifically concerned with provision of relief services and materials to victims of war and natural disaster. This point is vividly emphasized by Douzinas (2001) who notes that the principles of humanitarian action as enshrined in the guidelines of ICRC, have become the "rule book" of humanitarian action because, other humanitarian groups working to assist victims of war have adopted them as guiding principles.

From the evolution of traditional humanitarianism, it is undoubted that the Dunant's view of humanitarian action as a nonpolitical duty geared towards victims of war is the underlying force of humanitarian assistance. However, since the 1980s, classical humanitarianism has encountered unending challenges emanating from politicization of humanitarian aid intervention (Barnett and 
Weiss (2008). One of the major consequences of such deep politicization is the continuous attack and assault on humanitarian principles, especially the principle of neutrality. With the new typology of wars which manifested from the post-Cold War era and the complex emergencies it engendered, the tide of classical humanitarianism not only appeared to be winding, adherents of humanitarian principles began to lose much grounds in situations where it was obvious the state has become a predator of its subjects. Moreover, post-Cold War conflicts witnessed a geometric increase in the number of Non-Governmental Organizations (NGOs) working in conflict affected areas (Mawlawi, 1993). One significant effect of the proliferation of NGOs during this period is the expansion of their roles beyond mere relief to the suffering victims of war and natural disaster. While some encapsulated developmental projects (long term) in their programs, others expanded towards human rights promotion. It was such an expansion of roles that ushered in an era that has been described as “new humanitarianism' (Duffield, 2001; Mills, 2005). If traditional humanitarianism is anchored on neutral provision or relief that transcends politics, in the era of "new humanitarianism", they as Fox (2001) notes, are also expected to "name and shame" the violators of human rights as well as pursue programs that will bring about long term development. How these NGOs will carry out the latter without getting entangled in politics constitutes a problem to traditional humanitarian actors.

Beyond humanitarian NGOs, the international community 
was not oblivious to massive violation of human rights associated with the post-Cold War period. Ethnic cleansing, genocide, crime against humanity and war crimes starred the world to the face in Rwanda, Bosnia, Yugoslavia and others within the first decade of the termination of the Cold War. It was crystal clear that despite the Geneva Conventions, the legal framework for International Law was inoperative with sovereignty as conceptualized in 1648 . The quest for a new framework that will superimpose the sovereignty of human being over that of the state reached its peak when the UN's Secretary General, Kofi Anam, in addressing the UN's General Assembly posed the ultimate question: "If humanitarian intervention is indeed an unacceptable assault on sovereignty, how should we respond to Rwanda, to Srebrenica, to gross and systematic violation of human rights that offend every precept of our common humanity?" (UN, 2000) It was in this context that the International Commission on Intervention and State Sovereignty (ICISS) was set up in 2000 under the auspices of the Canadian Government to seek for a new international consensus on how to address the question of human rights violation (ICISS, 2001). The commission in its report of 2001 formulated the concept of Responsibility to Protect (R2P), which from all indications is a reinterpretation of the traditional norms of non-intervention and national sovereignty to regulate international response to humanitarian crisis (Evans, 2008). The report asserts that where a state is unable or unwilling to protect its citizens, such responsibility is automatically transferred to the international community. In other words, the doctrine of R2P implies that sovereignty connotes responsibility. Whereby the sovereign fails to protect its subject, such failure implies loss of sovereign power. In 
this case, the international response through $\mathrm{R} 2 \mathrm{P}$ cannot be a violation of sovereign entity, since such sovereign authority is already lost with the failure to give protection to the citizens. R2P therefore replaces the old dictum of "if sovereignty, then nonintervention "with "if sovereignty, then responsibility". Thus, R2P as produced by the ICISS, re-conceptualized sovereignty not as a right or dominion but as a responsibility.

The doctrine of $\mathrm{R} 2 \mathrm{P}$ was adopted as a norm by the UN General Assembly during the world summit of 2005. As an organ of the UN responsible for maintaining international peace, the Security Council ratified the norm with Resolution 1674 in 2006. The Outcome Document specifically address four issues namely: protecting population from war crime, genocide, ethnic cleansing, and crimes against humanity. Its 3 pillars as outlined by the United Nations are:

- The primary responsibility for protecting population from genocide, war crime, ethnic leasing and crimes against humanity lies with the state

- International community has the responsibility to assist the state in carrying out this responsibility.

- The international community has the responsibility to use appropriate diplomatic, humanitarian and other measures in line with the UN's charter to protect population from such crimes where the state fails to do so.(UN, 2005). 
It is pertinent to note that the Outcome Document included some important guidelines on R2P. For instance,

- R2P will be involved on case by case

- Appropriate diplomatic and other peaceful means must be explored before an outright military operation. In other words the use of military action must be seen as the last resort.

- Humanitarian consequences of the intervention must be clearly seen as less than predicted outcome or result of inaction

- Military action must be kept on the proportion (UN, 2005, 2009).

Despite its popularity in the early days of adoption, R2P has received a plethora of criticisms which raise scepticism on its usefulness as an instrument of peace in the Twenty-First Century. The questions of When and How appear to be the basis upon which critics have raised doubts on its reliability for collective security without violation of sovereign rights and powers of constituted states. While moderate critics focus on issues of conceptual refinement, non- consolidation and implementation (Paris, 2014), the real critics of the doctrine are more concerned about the concept in its entirety especially the military intervention. Beyond the limitations of concept and implementation, the framework is equally conceived as an attempt to justify and entrench unequal international system. It is regarded as a conscious policy to strengthen and normalize western governance in former colonial states (Mamdani, 2010, Cunliffe, 2010) Post-colonial critique of 
Nwaka: From a De-politicization Duty of Care...

$\mathrm{R} 2 \mathrm{P}$ is based on the suspicion that reconceptualization of sovereignty will weaken the ability of less powerful states to be able to control and influence their own affair. The doctrine of R2P is further criticized for promoting war rather than peace. In a heated debate with Ramesh Thakur, O'Connell (2008) argues that the P in R2P should stand for peace i.e., Responsibility to "Peace" and not protection. According to her, R2P is not associated with peace but with war and thus should quietly be allowed to fade away (2009). $\mathrm{O}$ Connell further muted that the emergence of $\mathrm{R} 2 \mathrm{P}$ was a reflection of a "new militarism" in international relations (2010). Charlesworth (2010), Harris Rimmer (2015), Frazer and Hutchings (2014), equally pitch their tent against the war-stance of R2P. There are other critics that stand against the doctrine for making intervention on humanitarian grounds an obligation rather than the traditional discretionary right it earlier rested on (Pape, 2012). It is based on this that some analysts are more comfortable with humanitarian intervention than R2P. Furthermore, arguing that international relations have become increasingly hierarchical with stratified forms of sovereignty Chandler (2006) recognized immediately after it was adopted by the Security Council, the danger and threat $\mathrm{R} 2 \mathrm{P}$ poses to prevailing normative order. According to him, R2P accepted military humanitarian intervention with addition of prevention and rebuilding in the ICISS report simply to sell the doctrine (2010). Indeed, while R2P has been criticized for different reasons, what many of the critics seem to share in common, as aptly pointed out by Noelle (2018), is their 
perception of the framework as an instrument that contains "too much" rather than "too little".

One of the groups that have responded to the doctrine of $\mathrm{R} 2 \mathrm{P}$ with some sort of ambivalence in theory and in practice is humanitarian NGOs. The basis of their reactions as noted earlier appears not to have been coherently articulated in literature. Most importantly, the possible areas of synergy and integration are yet to be formulated. It is to these that the remaining sections of the paper are devoted.

\section{Understanding the Tension}

Upon the adoption of the doctrine of R2P, there was a lively hope among its advocates that humanitarian assistance will be integrated into the new framework (Luck 2008a). This view was particularly common among NGOs and the leading supporters of R2P within the UN. Speeches of the former UN Secretary, Ban Ki-Moon and the Special Adviser at the Assistant Secretary-level, Edward Luck, reflected this desire for close relationship between R2P and traditional humanitarian assistance. For example, in trying to establish the nexus between humanitarian action and R2P, Ban KiMoon in his Berlin speech in 2008 noted that the response of the international community "... should be deep, utilizing the whole preventive and protection tool kit available to the UN system, to its regional, sub-regional and civil society partners and members states themselves" (UN 2008). Similarly, in his emphasis on the need for integration, Luck (2008b) argues that the UN's mission of preventing and protecting human population from gross violation of human rights could be more realistic in terms of coordination, 
Nwaka: From a De-politicization Duty of Care...

operational efficiency and system-wide coherence if rebranded within the guidelines of the R2P. Furthermore, Luck and his colleagues have worked in collaboration with some NGOs to set up an operational linkage between R2P and humanitarian action. In fact, about six (6) senior NGO officials were involved in the draft report to the UN Secretary on R2P which finally emerged as the Secretary General Report on R2P in 2008. The report became the most comprehensive UN's view on the operationalization of the $\mathrm{R} 2 \mathrm{P}$, and on the link between the latter and humanitarian assistance. Moreover, some of the pro-R2P NGOs had by 2008 undertaken independent programs towards promoting the agenda of the R2P. A good example was the World Federation MovementInstitute for Global Policy (WFM-IGP) that set up R2P civil society in 2003 to advocate for effective delivery of R2P by both government and international community. However, despite all these gravitations towards the operationalization of $\mathrm{R} 2 \mathrm{P}$, the ambivalence of the humanitarian action practitioners is not disputable. Most humanitarian actors, especially relief organizations, remain averse to $\mathrm{R} 2 \mathrm{P}$ maintaining that it is a travesty of the principles of humanitarian action (Weissman, 2010).

One of the major problems that constitute a barrier to the integration of humanitarian action into R2P centers on its conceptualization and operationalization. Most aid practitioners, especially those that tilt more towards relief services, do not have a clear picture of R2P and how it is to be achieved. While the link between $\mathrm{R} 2 \mathrm{P}$ and humanitarian assistance is often recognized by 
them, $\mathrm{R} 2 \mathrm{P}$ is viewed as a state-centric doctrine that constitutes a deviation from the goal and methods of delivering aid to victims of war. The general notion is that the involvement of the state in the conceptualization and operationalization of the framework situates the doctrine within the politics of statism which the traditional relief bodies believe stands akimbo to effective delivery of service to war victims. In other words, $\mathrm{R} 2 \mathrm{P}$ is seen as a diversion from the historical trajectory of humanitarian industry marked by its depoliticized character. In differentiating between OCHA's mandate from R2P, an OCHA's policy adviser on the protection of civilians in Darfur according to Okeke (2011:15-16) remarked:

... OCHA is a civil service arm of the UN and thus does not provide any activity that is in anyway political. If a government of a state authorizes us to leave its country we must oblige. Our activities are directed by the UN's General Assembly Resolution 46/182 not the R2P.... It is true that some of the activities provided by OCHA such as its coordination of humanitarian assistance, helping to sustain livelihood and so on, can be characterized as aspect of R2P..., but UN member states are the main drivers of R2P.

Succinctly put, the political character of R2P from its establishment constitutes a formidable force against its integration with humanitarian action which is seen as a non-political and altruistic endeavour. Closely associated with the above is the fact that some humanitarian practitioners have little understanding of the meaning of $\mathrm{R} 2 \mathrm{P}$ and its connection to their work. In responding to a question 
on how R2P is connected to his work in Darfur, another OCHA official noted that he was an expert in delivery of humanitarian assistance and not protection (Okeke, 2011), In fact, the official indicated his willingness to refer his interviewer to the UN experts on civil protection. An evidence of poor understanding with regards to R2P is crystallized in the distinction the OCHA official made between humanitarian assistance and protection. The former is seen as the delivery of assistance to victims of war and natural disaster while the latter is linked to the ICRC that got it popularized in 2000. In other words, despite the fact that there is a growing recognition of the need for collective responsibility in giving protection to victims of war and human rights violation by humanitarian organizations, such responsibility is generally linked to the ICRC and not a general preoccupation of humanitarian aid workers (Pantliano, et al, 2006).

Again the pacifist stance of some humanitarian NGOs makes them sceptical of R2P.Although a good number of these NGOs are presently members of the International Coalition for the $\mathrm{R} 2 \mathrm{P}$, their linkage to anti-war and peace activist campaign continues to shape their policies. Relief agencies in particular, as Noele (2018) argues, are slow to embrace approaches they believe may apply military means to terminate war or promote human rights. This is clearly evident in the words of Weissman $(2010,191)$ who maintains that: "if the purpose of humanitarian action is to limit the devastation of war, it cannot be used as a justification for new wars" The pacifists' scepticism which is common among 
organizations such as ICRC and Medecins Sans Fronterers equally stands in the way of integration. Moreover, the use of force appears to be standing against de-politicized impartial and neutral stance of humanitarian assistance. When force is applied as was found in Libya, one of the belligerents is likely to be treated as a monster.

The impact of the military content of the R2P to aid delivery is another reason that sustains the gap between humanitarian assistance and the new doctrine. Stoddard et al (2009) in their analysis of fatalities among humanitarians shows an increase in deliberate attempt on the lives of humanitarian workers. According to Weissman (2004) the attack in Afghanistan which claimed the lives of 4Medecins Sans Fronterers personnel on the $11^{\text {th }}$ of June 2004, was a consequence of confusion emanating from militarization of the humanitarian aid sector. The use of military to deliver humanitarian aid to war victims is seen as an infringement on the principle of humanitarian assistance - a development many regard as responsible for eroding humanitarian space in the $21^{\text {st }}$ century. Humanitarian assistance is dependent on the willingness of conflict parties to allow aid workers into their territories. Where such permission is denied, humanitarian workers respect the sovereignty of the state. Reliance on the military for delivering humanitarian assistance pitches humanitarian groups against one of the parties. The military, whether of regional or global intervention, is, in most cases, implicitly in support of one of the parties to the conflict. For example, while NATO's intervention in Libya was projected as an international response to save the defenceless civilians, there was no doubt that the coalition group was working to give credence and validity to the National Transition Council (NTC). A humanitarian group that receives the help of NATO to 
deliver aid to Libyans will automatically be perceived as part of the coalition against the Libyan leader, Mummer Gadhafi.

Finally, with R2P, humanitarian workers are likely to face obstruction where the international community has taken action against a state. Since R2P is a superimposition of the protection of people over sovereignty, a state that is losing its sovereign power due to international collective action is likely to find a scapegoat in non-political entities like relief organizations. Expulsion of 13 international and 3 local NGOs as found in Sudan following the International Criminal Court's (ICC) indictment of President Bashir, subjected relief organizations in that war-torn country to a dilemma of leaving Sudan or relying on the military for delivering humanitarian assistance.

In summary, the yearnings of the framers of the doctrine of $\mathrm{R} 2 \mathrm{P}$ and its advocates for an integration of traditional humanitarian action into the new framework is being hindered by a number of factors among which are: limited understanding of $\mathrm{R} 2 \mathrm{P}$ and what it entails, its political stance against historically-depoliticized tradition of humanitarian assistance and most importantly, R2P's association with the use of force which, from all indications, signals an end to humanitarian space as envisioned by Henri Dunant. The question is: are there some areas of synergy?

\section{Areas of Common Grounds}

Classical humanitarianism may evince some forms of ambivalences in relation to Responsibility to Protect, no doubt, but 
some areas of common grounds appear to be negating, to some considerable extent, the basis of such ambivalence. Beyond the biological inclination which Haskel (1985), pointed as the foundation of humanitarianism, the rise of humanitarian action has some religious underpinnings (Calbouu, 2008; Krafess, 2005). In formulating the doctrine of R2P, ICISS adopted the principles of the Just War Theory which originates in Christian Philosophy. Included in Thomas Aquinas conditions for a ust war are:

- War must be drafted by a properly instituted authority such as the state which represents the common good of all.

- War must be embarked upon not for self-gain but for a good and just purpose

- Peace must be central even in the midst of war (Gonzale, 1984

The Catechism of the Catholic Church also outlined four conditions for legitimizing the use of force (military)

- The damage inflicted on the nation or community of nations must be lasting, grave and certain.

- All other means of putting an end to it must have been explored without success

- There must be serious prospect of success

- The use of arms must not produce evil and disorder that are graver than the evil to be eliminated. (CCC, 2000)

If $\mathrm{R} 2 \mathrm{P}$ is premised on the religious principles of the just war theory, then, the inclusion of the just war criteria in the Report of the ICISS on $\mathrm{R} 2 \mathrm{P}$ suggests that the basis for alliance and cooperation between 
old humanitarianism and R2P exists. Traditional humanitarian actors, as earlier noted, are committed not only to delivery of humanitarian aid to war victims, but are also eager to influence positively the conduct of war in order to minimize its negative consequences on war victims. By implication, promoting the wellbeing of war victims from the just war dimension, may require force, when all other peaceful and diplomatic options have been explored without success, and when the negative effects of force are less reprehensible than inaction. Hankins, (2013) observes that many humanitarian organizations remain sceptical to R2P despite this co-relation. Arguably, humanitarian bodies are not averse to the use of force, but abhor the irresponsible use of force. The World Council of Churches (WCC) in its rejection of the framework adopted the concept of "Just Peace" which stands against the use of force except for exceptional circumstances. Although "Just Peace" in embracing social justice, rule of law, human rights and shared human security endorses R2P in principles, WCC (2011) feels obliged to "...challenge any theological or other justifications for the use of military power and considers this reliance on the concept of the just war (in the era of militaristic tendencies - my emphasis) to be obsolete". In other words, while the WCC "Just Peace" supports the content of the R2P, the other use to which the doctrine could be put (pretext for war) is rejected. From this, one could argue that rather than outright rejection of the new framework, traditional humanitarian actors are seeking to bring to the fur an implied aspect of the $\mathrm{R} 2 \mathrm{P}$ - responsibility in protecting, 
which though dormant in the $\mathrm{R} 2 \mathrm{P}$ document, is critical to humanitarianism.

Both old and new humanitarianism appear to have recognized the growing need for a collective responsibility to protect civilians caught up in violent conflict. R2P gives the international community the power to use all possible peaceful and diplomatic means, and force (as last resort if need be) to protect human population from genocide, ethnic cleansing, war crime and crimes against humanity. Whatever approach - preventive, diplomatic, and force, it takes, protection of human population is central to the doctrine as a collective responsibility. Protection as part of traditional humanitarianism was made popular for the first time by the ICRC through a series of protection workshop organized between 1996 and 2000 (ICRC, 2008). The body defines it as "... all activities aimed at obtaining full respect for the right of the individual in accordance with the letter and spirit of the relevant bodies of law (i.e Human Rights Law, International Humanitarian Law and Refugee Law)" (quoted in Bagshaw and Pau 2004:37). The ICRC concept of protection is an all-embracing one that seems to have encapsulated humanitarian assistance. For example, in one of its reports, ICRC projected the notion of protection further as action that "...makes it possible to stimulate the potential links between assistance, prevention and protection". The body maintains that "its assistance delivery, promotion of legal norms, communication, campaigns and confidential representations may all be part of a coherent protection strategy addressing the causes and consequences of violation and abuses" (2008:10). It is based on this position of ICRC that humanitarian groups, as Pantuliano et al (2006) observe, do refer to complex emergencies occasion by 
conflicts as "protection crises". However, the problem Okeke (2011) has pointed out is that rather than subsume that collective responsibility to protect within the R2P framework, humanitarian organizations and their field workers link it to ICRC and nothing more, as if they have nothing to do with R2P

Finally, traditional humanitarianism seems to have recognized, albeit subtly, the sanctity of human life and its superiority over sovereignty. Though many humanitarian bodies especially relief organizations, still hold to a high premium, the principles of humanitarian assistance particularly the controversial neutrality, there were occasions in the past when humanitarian organizations pursued relief program without the permission of the state involved. The situation in Biafra between 1968 and 1970 necessitated the formation of Joint Church Aid by more than 30 humanitarian groups to airlift relief items to the blockaded millions of people dying of hunger in Biafra without the consent of the Federal Military Government of Nigeria (Nwaka, 2014, 2015). Believing that there is no moral justification for starvation as instrument of war, Caritas and other humanitarian bodies in JCA superimposed the lives of human population in Biafra over territorial integrity being claimed by the Gowon-led military government of Nigeria. Even the ICRC continued its humanitarian assistance in both Nigeria and Biafra despite a deluge of criticisms to terminate such services until its relief plane was shot down in mid-1969 by the Nigerian bombers (Obiaga, 2004). That humanitarian groups could pursue their program of relief in Biafra 
without acquiescence from the Federal Military Government of Nigeria is an indication that the conscience of the world cannot be deadened by the Westaphalian sovereignty. When stark violation of human rights such as genocide, ethnic cleansing, mass starvation and the like are met with inaction or suspension of action from humanitarians, except in the case of grave danger such as massive diversion of aid or threat to the lives of aid workers, that in itself is within the purview of politics which stands against the depoliticized nature of action. Humanitarian neutrality as Nwaka (2014) argues differs from philosophical or absolute neutrality. While the later incapacitates the actor in a given situation, the former demands neutral, impartial, and humane action to save lives. Hence humanitarian neutrality as found in Biafra, like the R2P, establishes the superiority of human life over sovereignty - a stance relief organization championed in Africa's most populous country for more than three decades before its official adoption in 2005 .

\section{Conclusion}

The relationship between old and new humanitarianism has been ambivalent in nature. This, however, does not suggest that integration of the two as envisioned by the framers and advocates of R2P cannot be achieved. While there are grounds on which some humanitarian organizations isolate their activities from $\mathrm{R} 2 \mathrm{P}$, there are stronger basis as demonstrated above on which integration can be worked out. Moreover, the basis upon which R2P is rejected is not informed by inadequacies in the content of the new framework, for both old and new humanitarianism appear to be pursuing similar goal - protection of helpless victims of war. What constitutes a difference seems to be too much space in $\mathrm{R} 2 \mathrm{P}$ which (1) could be 
exploited by powerful states for personal gain and (2) stifles the implied but most important aspect of the doctrine - responsibility in protection.

Rev. Sr. Dr. Jacinta Chiamaka Nwaka teaches History at the Department of History and International Studies at the University of Benin, Edo State. 


\section{Reference}

Acharya, Amitav, 2013. "The R2P and Norm Diffusion: Towards a Framework of Norm Circulation", Global Responsibility to Protect 5, 4, 466-479

Acharya, Amitav, 2015. "The Responsibility to Protect and a Theory of Norm Circulation", in Theorizing the Responsibility to Protect, edited by Ramesh Thakur and William Maley Cambridge: Cambridge University Press, 5978.

Bagshaw, S. and D. Paul, 2004, Protect or Neglect? Toward a More Effective United Nations Approach to the Protection of Internally Displaced Persons: An Evaluation, The BrookingsSAIS

Project on Internal Displacement and The UN Office for the Coordination of Humanitarian Affairs Inter-Agency Internal Displacement Division, Washington DC.

Barnett, Michael. N. and Thomas George Weiss, 2008. "Humanitarianism: A Brief History of the Present," in Humanitarianism in Question: Politics, Power, Ethics, edited by Barnett, Michael. N. and Thomas George Weiss, 2008. Ithaca NY, Cornell University Press. 1- 48.

Calhoun, Craig., 2008, "The Imperative to Reduce Suffering: Charity, Progress, and Emergencies in the Field of Humanitarian Action," in Humanitarianism in Question: 73- 
Nwaka: From a De-politicization Duty of Care...

97.

Catechism of the Catholic Church, $20002^{\text {nd }}$ Edition, Liberia Editrice Vaticana,

Chandler, D., 2004. "The Responsibility to Protect? Imposing the 'Liberal Peace," International Peacekeeping, 11(, 1, 59-81.

Chandler, David, 2006. From Kosovo to Kabul and Beyond: Human Rights and International Intervention. Pluto Press.

Chandler, David, 2010. "R2P or Not R2P? More State building,

Less Responsibility" Global Responsibility to Protect 2, 1, 161-166.

Chandler, David, 2015. “The R2P Is Dead, Long Live the R2P: The Successful Separation of Military Intervention from the Responsibility to Protect". International Peacekeeping 22, 1, 1-5.

Charlesworth, Hilary.2010. "Feminist Reflections on the Responsibility to Protect," Global Responsibility to Protect 2, 3, 232-249.

Chilaka, F. I. Chigozie and A. Ugwu, 2013. "NATO's 2011 Intervention in Libya: Beyond Humanitarian Intervention" Net Journal of Social Science 1, 5-10.

Crossley, Noele, 2018. "Is R2P Still Controversial? Continuity and Change in the Debate on Humanitarian 
Intervention," Cambridge Review of International Affair, 31 5, 1-21.

Cunliffe, Phillip, 2010. "Dangerous Duties: Power, Paternalism and the 'Responsibility to Protect"' Review of International Studies 36, special issue, 79-96.

Cunliffe, Philipp, 2016. "The Doctrine of the 'Responsibility to Protect' as a Practice of Political

Exceptionalism," European Journal of International Relations 23:2, 466-486.

De Torrence N., 2004. "Humanitarianism Sacrificed: Integration's False Promise," Ethics and International Affairs 18, 2, 3-12.

Douzinas, C., 2007. "The Many faces of Humanitarianism,' Parrbesia, 1,2,1-28.

Duffield, M., 2002. "'Aid and Complicity: The Case of WarDisplaced Southerners in the Northern Sudan," The Journal of Modern African Studies, 40,1, 83-104.

Duffield, M. 2001, Global Governance and the New Wars: The Merging of Development and Security, London: Zed

Dunne, Tim and Staunton, Eglantine, 2016. "The Genocide Convention and Cold War Humanitarian Intervention" in Oxford Handbook of the Responsibility to Protect edited by Alex Bellamy and Tim Dunne, Oxford: Oxford University Press, 38-57.

Evans, Gareth, J 2017. "Taking Stock of the Responsibility to Protect: Achievements and Challenges", public lecture, 
Nwaka: From a De-politicization Duty of Care...

Simon Fraser University, Vancouver, 22 March 2017. Available at

http://www.thesimonsfoundation.ca/sites/default/files/Tak ing\%20Stock\%20of\%20the\%20Responsibility\%20to $\% 20$ Protect-

Achievements\%20and\%20Challenges $\% 2 \mathrm{C} \% 20$ public $\% 2$ 0lecture\%20by\%20G.Evans\%2C\%20March\%2022\%2 02017_1.pdf. Last accessed 13/03/2018.

Evans, Gareth .J., 2008. The Responsibility to Protect: Ending Mass Atrocity Crimes Once and for all. Washington DC: Brookings Institution Press.

Fox, F., 2001. "New Humanitarianism: Does It Provide a Moral Banner for the $21^{\text {st }}$ Century?' Disasters, 25, 4, 275-89.

Frazer, Elizabeth and Hutchings, Kim, 2014. "Revisiting Ruddick: Feminism, Pacifism and Non-Violence" Journal of International Political Theory 10, 1, 109-124.

Gonzale Justo L. 1984. The Story of Christianity, San Francisco: Harper

Hall, Ian, 2016. "Perilous Interventions and the Responsibility to Protect, Special Forum on Hardeep Singh Puri's Perilous Interventions: The Security Council and the Politics of Chaos" Global Responsibility to Protect 9, 203-210. 
Haskel T.L, 1985. "Capitalism and Origin of Humanitarian Sensibility," Part 1 American Historical Review, 90, 2, 559361.

Hankins, Rick, 2013. "Confronting Genocide: Christianity and the Responsibility to Protect" PhD. Dissertation Claremont Graduate University.

Harris-Rimmer, Susan, 2015. "Is the Responsibility to Protect Doctrine Gender-Neutral?" in Theorizing the Responsibility to Protect, 266-284.

International Committee of the Red Cross, 2008. Enhancing Protection for Civilians in Armed Conflict and Other Situations of Violence, ICRC: Geneva.

International Commission on Intervention and State Sovereignty, 2001. The Responsibility to Protect: Report of the International Commission on Intervention and State Sovereignty, Ottawa

Kaldor, M., 2001. New and Old Wars: Organized Violence in a Global Era. Cambridge: Polity Press.

Krafess, J., 2005."The Influence of the Muslim religion in humanitarian aid," International Review of the Red Cross 87, 858, 327-42.

Luck, E., 2008a. "Draft Report for the Secretary-General on the Responsibility to Protect-Confidential."

Luck, E.2008b, "The United Nations and the Responsibility to Protect," in Proceedings of the Stanley Foundation Policy Analysis Brief, Iowa: Stanley Foundation

Macrae, J., 2000. "Humanitarianism: Facing New Challenges," Great 
Decisions, 81-96.

Macrae, J. and A. Harmer, 2003. Humanitarian Action and the 'War on Terror': a Review of Issues, HPG Report 14, London: Overseas Development Institute.

Mamdani, Mahmood, 2010. "Responsibility to Protect or Right to Punish?” Journal of Intervention and Statebuilding 4, 1, 5367.

Mamdani, Mahmood, 2009. Saviors and Survivors: Darfur, Politics and the War on Terror, London: Verso.

Mawlawi, F., 1993. "New Conflicts, New Challenges: The Evolving Role of Non- governmental Actors,' Journal of International Affairs, 46 2.391-413.

Mills, K., 2005. "Neo-Humanitarianism: The Role of International Humanitarian Norms and Organizations in Contemporary Conflict," Global Governance, 11, 2, 161-83.

Nwaka, J.C. 2015. "Reactions of the Governments of Nigeria and Biafra to the Role of the Catholic Church in the NigeriaBiafra War," War and Society 34, 1, .65-83. Available at https://doi.org/10.1179/0729247314200000000 Accessed $\underline{7 / 8 / 2020}$

Nwaka, J.C., 2013. "When Neutrality Loses its Values: Caritas Airlift to Biafra, 1968-1970," Journal of the Historical 
Society of Nigeria, 22, 63-81. Available at https://www.jstor.org/stable/24768917 Accessed 7/8/2020

Obiaga, N., 2004. The Politics of Humanitarian Intervention in the Nigerian Civil War, Africa World Press.

O Connell, Mary Ellen and Thakur Ramesh, 2008, "The R2P Controversy" Available at https://www.global policy.org/component/content/article/154/26068.html.Acce ssed, 4/9/2019

O Connell, Mary Ellen 2009,"Sri Lanka Needs Peace, Not R2P" Available at

https://wwwir,infor/2009/04/28/sri-lanka-needs-peace-not-r2p,

Accessed, 4/9/2019

O Connell, Mary Ellen. 2010, "Responsibility to Peace: A Critique of R2P" Journal of Intervention and Statebuilding, 4, 1. 39-52.

Okeke, J.M., 2010. "Contextualizing the Responsibility to Protect; in Darfur," International Journal of African Renaissance Studies, 5,1, 65-81.

Okeke J.M. 2011. "Why Humanitarian Aid in Darfur is not a Practice of Responsibility to Protect," Discussion Paper, Nordic African Institute,

Pantuliano, S. and S. O'Callaghan, 2006. The Protection Crisis': A Review of Field-based Strategies for humanitarian Protection in Darfur. HPG discussion paper. London: Oversea Development Institute. 
Nwaka: From a De-politicization Duty of Care...

Pape, Robert A, 2012. "When Duty Calls: A Pragmatic Standard of Humanitarian Intervention" International Security, 37, 1. 41-80

Paris, Roland, 2014. "The Responsibility to Protect and the Structural Problems of Preventive

Humanitarian Intervention," International Peacekeeping, 21, 5, 387-415.

Puri, Hardeep Singh, 2016, Perilous Interventions: The Security Council and the Politics of Class, Harper Collins

Sampford, Charles and Thakur Ramesh, 2015, "From the Right to Persecute to the Responsibility to Protect: Feuerbachian Inversions of Rights and Responsibilities in State-Citizen Relations" in Theorizing the Responsibility to Protect, edited by Thakur Ramesh and Maley William, Cambridge: Cambridge University Press, 38-58.

Stoddard, A., A. Harmer, and V. Didomenico, 2009, "Providing Aid in Insecure Environments: 2009 Update Trends in Violence against Aid Workers and the Operational Response," HPG Policy Brief, 34, 1-12. London: Oversea Development Institute.

Thakur, Ramesh, 2017. "From Humanitarian Intervention to R2P: Cosmetic or Consequential?" in The United Nation Peace and Security: From Collective Security to the Responsibility 
to Protect $2^{\text {nd }}$ edition, edited by Thakur Ramesh, Cambridge:

Cambridge University Press, 272-300.

United Nations, 2008. Secretary General Defends and Clarifies

'Responsibility to Protect' at Berlin Event on Responsible

Sovereignty: International Cooperation for a Changed World, SG/

SM/11701, UN Department of Public Information, New York.

United Nations, 2005. "World Summit Outcome", General Assembly A/60/L.1 www.un.org

United Nations 2009, "Implementing the Responsibility to Protect:

Report of the Secretary

General" A/63/677 www.un.org

United Nations 2000. We the Peoples: the Role of the UNs in the $21^{\text {st }}$ Century, Washington DC: United Nations

World Council of Churches, 2011. An Ecclesiastical Call to Just Peace, Geneva

Weissman, Fabrice, 2010, "Not in Our Name: Why Medecins Sans

Frontieres Does not Support the "Responsibility to Protect,"

Criminal Justice Ethics, 29, 2. 194-207.

Weissman, Fabrice, 2004, "Humanitarian Actions and Military Intervention: Temptations and Possibilities," Disaster, 28, 2, 205-215.

Weiss, Thomas G. 2011."Rto P Alive and Well after Libya," Ethics and International Affair, 25, 3, 287-292. 